\title{
Opinions of Primary Teacher Education Students on Extra-Curricular Activities in Education
}

\author{
Hatice Yildiz ${ }^{1} \&$ Ebru Bozpolat ${ }^{1}$ \\ ${ }^{1}$ Faculty of Education, Sivas Cumhuriyet University, Sivas, Turkey \\ Correspondence: Hatice Ylldiz, Faculty of Education, Sivas Cumhuriyet University, Sivas, Turkey. E-mail: \\ yildiz_htc@yahoo.com
}

Received: June 3, 2021

Accepted: July 7, $2021 \quad$ Online Published: July 12, 2021

doi:10.5539/jel.v10n4p213

URL: https://doi.org/10.5539/jel.v10n4p213

\begin{abstract}
The aim of this study is to reveal the opinions of the Primary Teacher Education students in terms of the Extra-Curricular Activities in Education (ECAE) course. In this study, in which a qualitative research method was used, the case study design was preferred. In this context, the subjects of the research consist of 77 Primary Teacher Education students studying in Sivas Cumhuriyet University, Faculty of Education. Data were collected through a semi-structured interview form consisting of 7 open-ended questions. The content analysis method was employed in the analysis of the data. As a result of the research, it was determined that most of the students did not have an idea on the ECAE course at the beginning of the term. The ECAE course contributed to the students in "Cognitive", "Social", "Affective" and "Psychomotor" fields. The ECAE course improved the skills of receiving support, increasing self-confidence in public, and establishing an ability to communicate about communication with stakeholders. While preparing the activities related to the ECAE course, the students encountered problems related to the activity, personal, intra-group, technical, material related, time, official procedure, and place problems and they offered solutions to these problems. The ECAE course enabled students for learning material properties, developing handicraft skills, developing creativity, improving imagination, augmenting one's willingness to utilize materials, increasing the frequency for utilizing materials, and ensuring ideas to be put into practice regarding students' skill to utilize materials. Finally, the ECAE course positively affected the students' skills to use educational technology. The students stated that they learned to use a computer, to make use of the internet, how to use technology more effectively, and that they became practical in utilizing the technology.
\end{abstract}

Keywords: extracurricular activities, primary school teaching, student

\section{Introduction}

The education which expresses the process in which knowledge, attitude, and behavior of an individual develops, has been defined, with its most common description, as "the process of deliberately creating a demanded change in one's behavior through his/her own life" (Ertürk, 2013, p. 12). The skills of students for gaining knowledge and becoming skillful at something in a demanded direction depend on having effective and productive learning experiences in educational institutions (Demirtaş, 2017, p. 757). The teaching must be given in a planned route to get an effective and efficient education, that is, some well-organized curricula must be prepared.

The curriculum, which is defined as "the mechanism of learning experiences provided to the learner through scheduled activities both at school and out of school" (Demirel, 2014, p. 4), includes all of the activities aimed at for realizing the learning expected from students (Büyükkaragöz, 1997, p. 17). Oliva and Gordon (2018, p. 6) defined the curriculum as the schedule, plan, content, and learning experiences. Tanner and Tanner (1990, p. 197) stated, on the other hand, that the curriculum was consisted of factors such as "a scheduled learning environment, and organized knowledge, including cognitive/affectional content and process, and objectives and outcomes, etc." Should the need arise to put forward this definition more systematically, the curriculum is the harmonizing the educational objectives and expected outcomes with contents prepared in cognitive/affectional aspects and also with the learning-teaching process to provide the students with guidance.

It seems possible to claim that the generally accepted classification is the one of Posner (2004, pp. 12-14) though different classifications related to the curriculum are available in the literature. Posner divided the curriculum types into five groups as (1) official curriculum, (2) operational curriculum, (3) null curriculum, (4) extra-curriculum, 
and (5) hidden curriculum. The official curriculum is a schedule that is described in official documents (Castaño \& Kelly, 2012) prepared usually by curriculum experts. The official curriculum contains detailed information relating to objectives, content, learning and teaching process, and assessment and evaluation (Marsh, 1997). The operational curriculum is a schedule available in the actual teaching practices. Posner (1995, as cited in Demirel, 2014 , p. 4) defined this curriculum as a schedule that covers the issues which a teacher desires to teach in class, how they are taught in the learning-teaching process and the learning outcomes of students. Although the null curriculum is available in the official curriculum, it is both not taught and included in the class. Since it is physically impossible to teach everything at school, many subjects or units are deliberately excluded from the official curriculum and not implemented (Assemi \& Sheikhzade, 2013, p. 83), and it constitutes, therefore, the disregarded part of the official curriculum. The extra curriculum consists of experiences to be planned independently from the official curriculum. The teaching activities settled only through official curricula cannot be sufficient enough for the development of children. In addition to the teaching activities included in the official curriculum, the extra curriculum activities can be applied for both the cognitive and physical development of children accordingly. These activities refer, in general, to non-academic activities that support academic skills (student clubs, excursions, ceremonies, musical events, sports, etc.) (Taneri, 2018, p. 59). The hidden curriculum means, meanwhile, the institutional norms that are not explicitly accepted but play a supreme role at schools and in society (Poetter \& Badiali, 2001, p. 138). The hidden curriculum is related to the values of society and the culture of a school. The themes as the learning environment, attitudes and expectations of teachers, ways of overcoming conflicts, relations with family and neighborhoods, quality of communication, participation of students in decision-making processes, management approach of school administration and teachers, and general policy and philosophy of a school altogether constitute the culture of a school and so indirectly the hidden curriculum of a school (Halstead \& Taylor, 2000, as cited in Akman, Kılıç Çarşanbalı, \& Alagöz, 2017, p. 704).

The hidden curriculum has at least as vigorous effects as the official curriculum though it is not available in written form. Giroux and Penna (1979, p. 22) defined the hidden curriculum as unexpressed norms, values, and beliefs that are conveyed to students through the principal structure in both the official curriculum and the social relations of school and classroom life. The hidden curriculum serves significantly to the values education. For example, many values such as respecting for elders, helping each other, sharing, respect for human rights, taking into consideration the differences, being responsible, being patriot, etc. are implicitly given to students at schools, through hidden curricula, as well as official curricula, through attitudes and messages. The activities outside of school or outside of the classroom also contribute directly, as distinct from the official curriculum implemented at school, to the values education. İșcan $(2019$, p. 44) has defined these activities, namely "extra-curricular activities", as "the activities that are accomplished out-of-class hours, enrich the knowledge that students grasped during course, canalize the skills and interests of students, and give students a sense of citizenship".

The extra-curricular activities are the resources that schools offer to their students and students prefer to spend their time and energy on them (Stearns \& Glennie, 2010, as cited in İşcan, 2019, p. 44). Among the fields involved in the extra-curricular activities are sports, games, arts, music, drama, theater, art activities such as poetry, student newspaper, clubs, miscellaneous social events, etc. (Annu \& Sunita, 2013, p. 92; Cadwallader, Wagner, \& Garza, 2002, p. 1; İşcan, 2019, p. 43; Lunenberg, 2010, p. 1).

The studies on extra-curricular activities are very limited. In the studies, the concepts of out-of-school activity or out-of-class activity were used instead of the concept of extracurricular activity. In the literature, studies have been conducted on subjects such as the evaluation of extracurricular activities applied at any school level (Kocayiğit \& Ekinci, 2020), the classification of extracurricular activities (Köse, 2013), the effect of extracurricular activities on some variables (Akyüz, 2013; Taşoğlu, 2010; Yıldırım, 2019), and students' views on extracurricular activities (Avc1 \& Gümüş, 2019). As can be seen, there is no research in the literature on how to teach extracurricular activities in teacher education or the effectiveness of such a course. In this respect, it is thought that the research will make important contributions to the literature as it is the first and unique studied subject.

The studies carried out indicate that participation in extra-curricular activities increases favorably the success of a student (Abizada, Gurbanova, Iskandarova, \& Nadirzada, 2020; Craft, 2012; Freeman, 2017; Jansen, 2016; Meadows, 2019). It is momentous, with this awareness, to initiate and sustain the extra-curricular activities in conformance with their purpose at schools. Based on this idea, the Institution of Higher Education (Council of Higher Education [YÖK]) added the "Extra-curricular Activities in Education" course to the list of selective pedagogical knowledge by making an arrangement in the Undergraduate Curricula for the Department of Teacher Education of the Faculty of Education in 2018. It has been planned to include in this class the themes as "official curriculum and extra-curricular activities/hidden curriculum concepts in education; approaches relating to the 
hidden curriculum; cognitive and affectional learning areas and hidden curriculum; school as a ritual place; school ceremonies as extra-curricular activities at school; prominence and management of social, cultural, sporty, and artistic activities at school; the place and importance of the hidden curriculum for values education; extra-curricular activities for values education (commemoration, celebration, meeting, graduation, etc.)" (YÖK, 2018).

The pedagogical knowledge courses for teaching are courses that aim to teach the students how to teach students the knowledge they have been learning in the field knowledge courses and how to organize an educational environment for that purpose (YÖK, 2007, pp. 64-67; Taşkın \& Haciömeroğlu, 2010, p. 166). The students are expected, also in the ECAE course which is an optional pedagogical knowledge course, to acquire skills, which are among their educational duties, such as preparing and presenting ceremonies and transferring the virtues in the curriculum to students. Yurdakal (2018, p. 1496) reported that the training-teaching activities were not made up of only an official curriculum and so the ECAE course was a beneficial course also for teachers. It is considered, hence, that this course will have a great impact on the students' acquiring pedagogical knowledge and skills, and it is assumed that revealing student opinions on this course will add favorable contributions to the field.

The aim of the study, in this context, is to reveal the opinions of 2nd-grade students of the Primary Teacher Education in terms of the Extra-Curricular Activities in Education (ECAE) course. The responses to the following questions have been asked for within the framework of this principle purpose:

1) What were the opinions of the students on the ECAE course before taking it?

2) What are the opinions of the students on the contribution of the ECAE course?

3) What are the opinions of the students on the effects of the ECAE course in terms of communication with stakeholders?

4) What are the opinions of the students on the problems encountered during the ECAE course?

5) What are the suggestions of the students for the problems encountered during the ECAE course?

6) What are the opinions of the students on the effects of the ECAE course in terms of material utilization skills?

7) What are the opinions of the students on the effects of the ECAE course in terms of educational technology utilization skills?

\section{Method}

In this section the data gathered relating to the model of research, subjects, data collection, data analysis, and studies for validity and reliability were explained.

\subsection{Research Model}

The case study pattern, one of the qualitative research methods, was used in the study conducted to determine the opinions of 2nd-grade students of the Primary Teacher Education on the ECAE course. The case study is a research method that is based upon the questions 'how' and 'why', and it allows a researcher to examine a phenomenon or event that he/she cannot control in depth (Yıldırım \& Şimşek, 2013, p. 313). The cases may be individuals, groups, curricula, institutions, neighborhoods, cultures, regions, or nation-states. The purpose of the case study is to collect comprehensive, systematic, and in-depth information about each case. The case data consists of information collected about each case, such as interview data, observation records, documentation, and statements of others about the case, and contextual information (Patton, 2014, p. 449).

\subsection{Subjects}

Subjects were selected using the "criterion sampling" method, which is one of the purposeful sampling methods. The criterion sampling method is based upon the study of all cases that covers a predetermined set of criteria. The criteria may be built up by the researcher or a list of criteria to be prepared previously can also be applied (Marshall \& Rossman, 2014, p. 111; Yıldırım \& Şimşek, 2013, p. 140). The basic criterion used in determining the samples in this study is to select samples who attend the ECAE course, which is offered as an optional pedagogical knowledge course under the Department of Teacher Training Curriculum of the Faculty of Education and ones who actively participate in the class and covering the requirements of this class. In this context, the subjects of the research consist of 77 students studying in the 2nd grade of the Primary Teacher Education in the academic year 2019-2020. 59 of the students are female and 18 of them are male.

\subsection{Data Collection}

The data required in the study were collected through a "semi-structured interview form". A researcher intends, in the interview technique, to systematically reveal the thoughts and feelings of a target person under the guidance of 
questions which he/she'll prepare beforehand about the subject to be surveyed. The research objective is to systematically learn, understand, and define the subjective thoughts and feelings of a target person by asking him/her applicable questions about the area of study (Kvale, 1996, as cited in Türnüklü, 2000, p. 544). Semi-structured interviews are used typically when a researcher desires to review an issue in-depth and to understand accurately the responses to be collected (Harrell \& Bradley, 2009, p. 27).

The researchers first conducted, before preparing the interview form, a review of national-international literature regarding the study. As a result of the literature review, the questions that could be directed to the students within the scope of this study were prepared and a pool of questions was created accordingly. To get expert opinions in terms of the acceptability aspects of the research, the "Semi-Structured Interview Form" was submitted to an associate professor studying in the Department of Curriculum and Instruction. Taking into consideration the purpose of the research and the number of questions that could be included in the qualitative research, it was decided, in line with the expert recommendations, to combine two (2) questions that would serve for a similar purpose and to remove two (2) questions from the form. Büyüköztürk (2012) emphasizes that the validity of content and face of a measurement tool can be evaluated by taking expert opinions. It was tried, in this way, to fix up the validity of content and face of the measurement tool prepared. The interview form was restored to its final form accordingly. The form consists of 7 (seven) questions and two parts. Whereas the form has a blank area in the first part of it where the subjects can state their gender, the second part contains the questions to be asked to determine the opinions of the students on the ECAE course. All of the interview forms were applied, on a volunteer basis, to the students at the end of the semester after the ECAE courses were over. The aim and importance of the interview form were mentioned and applicable instructions on how to fill up an interview form were given to the students during the application.

\subsection{Data Analysis}

The content analysis method was utilized for analyzing the data obtained as a result of the study. The content analysis is a research technique used to draw recurring and valid conclusions from the data acquired about the content of the study (Krippendorff, 1980, p. 25). Four stages as encoding the data, determining relevant themes, arranging the codes and themes allocated, and interpreting the findings, were followed in this process (Yildirım \& Şimşek, 2013, p. 260). For this purpose, first, the student statements available on the interview form were computerized and then transferred into the NVivo10 program. During the data analysis phase, first, the student responses to each question were read over and over by the researchers, and the parts that constitute meaningful wholes were encoded accordingly. Then, the themes related to these encoded data were identified, the codes and themes were analyzed and put into final form, and then findings acquired commentated. The themes collected as a result of the content analysis and the relationships between these themes were put forth by models.

\subsection{Validity and Reliability Studies}

In this study, the criteria of credibility (for internal validity), transferability (for external validity), consistency (for internal reliability), and verifiability (for external reliability) were applied, grounding based on classification generated by Guba (1981, p. 80) in terms of the validity and reliability processes.

The internal validity of the study was tried to be achieved by employing the credibility criterion. A depth-focused data collection and expert reviews were included so that the credibility of the research could be amplified. The researcher must, while collecting the depth-focused data, permanently compare the results acquired with each other, interpret and conceptualize and reveal some relationships and structures that are not clearly noticed even by the subjects of the study (Yıldırım \& Şimşek, 2013, p. 301). For this reason, interview records were reread many times, the themes and categories were formed and the interview records were permanently compared to and re-evaluated within the framework of these themes and categories while analyzing the interviews. Also, the expert review was employed to expand the credibility. During the review phase, an expert evaluates critically the whole process in terms of the research design, data collection, analysis, the typing of the findings (Başkale, 2016, p. 24). Thence, the denominating of the themes determined and their conformance to the categories were backed up through expert opinions.

Lincoln and Guba (1985, p. 301) explained the concept of external validity in quantitative researches in terms of the concept of "transferability" in qualitative research. Two routes are recommended to ensure transferability in the qualitative research. The first route is in-depth description and the second is purposeful sampling (Erlandson, Haris, Skipper, \& Allen, 1993, as cited in Yıldırım \& Şimşek, 2013, p. 304). In order to ensure transferability in the study, the data attained were reported in detail, and data collection tools, data collection, and data analysis were submitted comprehensively to the reader. The findings obtained in the study were presented, on the other hand, backing up with direct quotations representing the opinions on the relevant theme. A system of descriptive coding 
such as S8-F ("S8" Student-8, "F" = Female) was introduced, taking into consideration personal privacy, at the beginning of direct quotations. The criterion sampling, one of the purposeful sampling methods, was chosen as the secondary provision for ensuring transferability while determining the subjects of the research. The units, objects, and events that cover the criteria specified for sampling are selected as samples in the criterion sampling (Büyüköztürk, Çakmak, Akgün, Karadeniz, \& Demirel, 2009, p. 95). The basic criterion used in selecting the samples was determined as, "to attend the ECAE course given as an optional pedagogical knowledge course in the Department of Teacher Training Program of the Faculty of Education and to meet the requirements of this course".

The consistency criterion in qualitative research is recommended instead of the concept of internal reliability in quantitative research (Guba, 1981, p. 80). Thus, data were transferred directly, without adding the comments of researchers, to the reader in order to ensure the consistency of the study. Additionally, the responses of students to the interview questions were analyzed by two researchers twice at different times, and then the researchers gathered, analyzing the questions again, and then the conflict was removed accordingly. As a result of the data analysis, a model was created with the codes and themes attained, and consistency was achieved, submitting examples from direct quotations.

The concept of verifiability was analyzed for the external validity of the research. For this purpose, Erlandson et al. (1993), Yıldırım and Şimşek (2013, p. 306) recommend the researcher compare the results obtained with the raw data to make sure if the confirmation mechanism has been operating appropriately. The forms obtained from student interviews, their computerized records, and the encodings allocated by both researchers during the analysis phase have been kept for review by concerned ones to ensure the verifiability of the research.

The Method section describes in detail how the study was conducted, including conceptual and operational definitions of the variables used in the study, Different types of studies will rely on different methodologies; however, a complete description of the methods used enables the reader to evaluate the appropriateness of your methods and the reliability and the validity of your results, It also permits experienced investigators to replicate the study, If your manuscript is an update of an ongoing or earlier study and the method has been published in detail elsewhere, you may refer the reader to that source and simply give a brief synopsis of the method in this section.

\section{Results}

The direct quotations, which represent the findings and statements obtained from the opinions of 2nd-grade students of the Primary Teacher Education on the ECAE course, are contained under this title.

\subsection{Student Opinions on ECAE Course Before Taking the Course}

The students were asked firstly, before taking the ECAE course, for their opinions on the course and the findings of students were given in Figure 1.

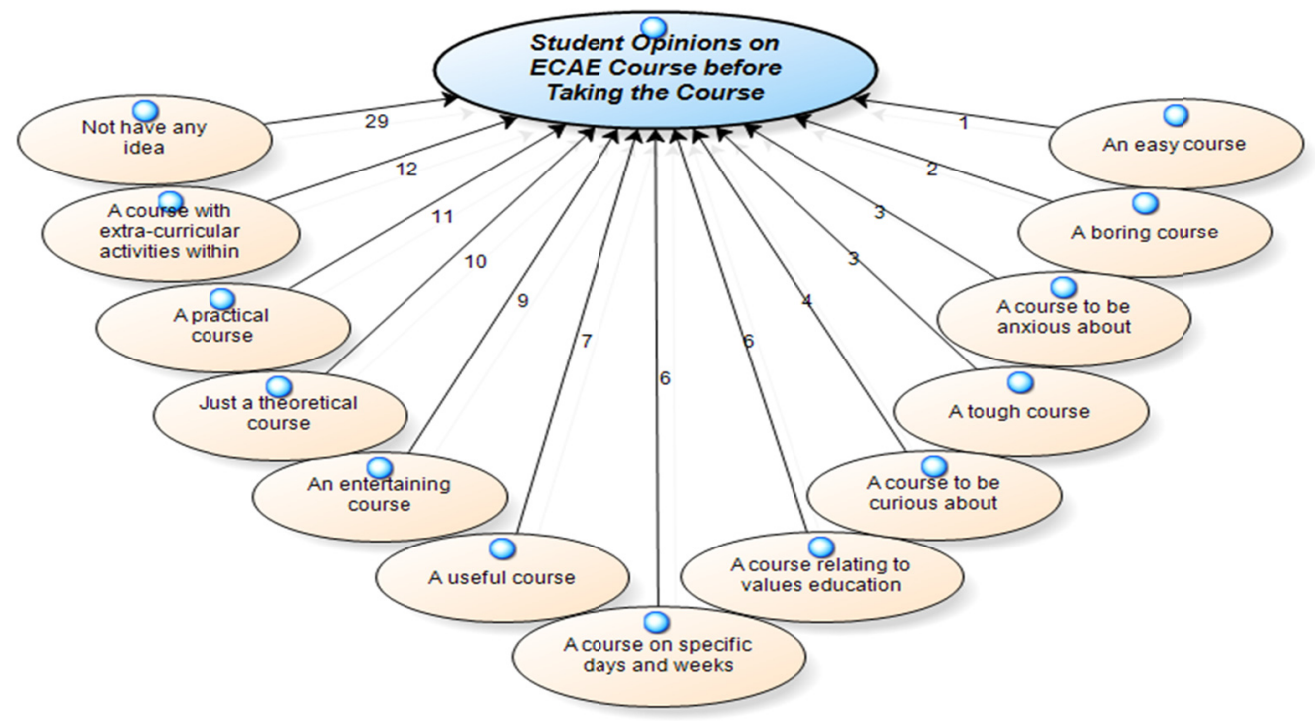

Figure 1. Student opinions on ECAE course before taking the course 
In Figure 1, when the student opinions on the course prior to taking the ECAE course were analyzed, it was seen that the majority of students did not have any idea (f: 29) about the course. The themes with the highest frequency were as "A course with extra-curricular activities within" (f: 12), "A practical course" (f: 11), "Just a theoretical course" (f: 10), "An entertaining course" (f: 9) and next as "A useful course" (f: 7), "A course on specific days and weeks" (f: 6), "A course relating to values education" (f: 6), "A course to be curious about" (f: 4), "A tough course" (f: 3), "A course to be anxious about" (f: 3), "A boring course" (f: 2) and "An easy course" (f: 1). The sample statements which are benefited from as a source of the student opinions on the course prior to taking the ECAE course are given below.

S57-M "I did not have any idea relating to this course before taking the ECAE course. I did not know what to do. As I got to familiarize with the course, I started to have a liking for it."

S65-F "I expected that there would be activities that we could participate in at out-of-class hours, not at school."

S9-F "I thought I would be active during this course. So it happened."

S48-F "I assumed that this course would be taught only theoretically, not with practices. Of course, the practical style is all the better because we shall be teachers hereafter."

S4-M “... it looked like it would be entertaining since the name of the course included activity within."

\subsection{Student Opinions Regarding the Contributions Provided Through the ECAE Course}

The question on what kind of contributions the ECAE course provided to them was directed to the students and the findings were given in Figure 2.

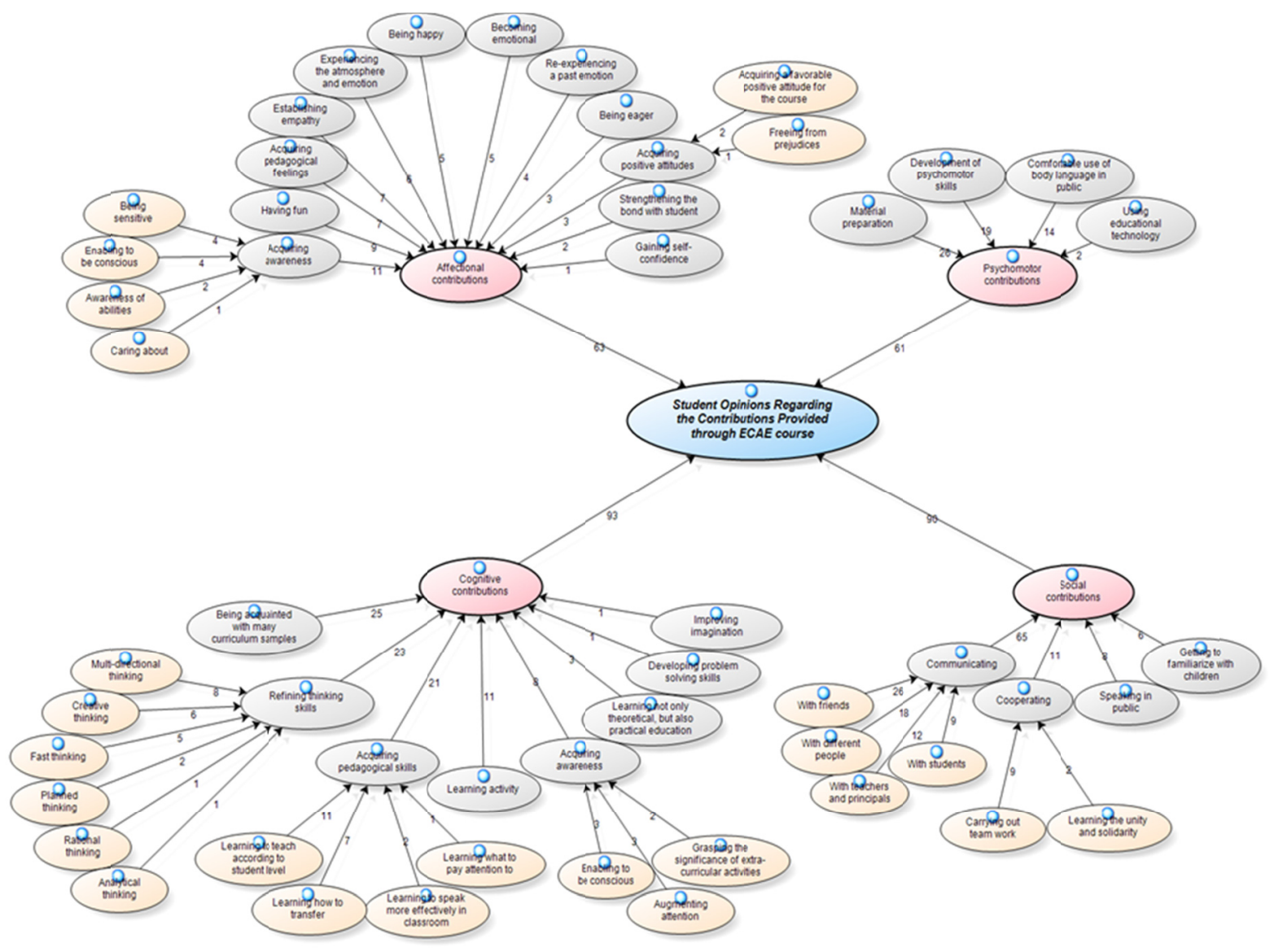

Figure 2. Student opinions regarding the contributions provided through ECAE course

In Figure 2, when the student opinions regarding the contributions of the ECAE course were examined, it was observed that their opinions were categorized under 4 (four) themes as, "Cognitive contributions" (f: 93), "Social 
contributions" (f: 90), "Affectional contributions" (f: 63), and "Psychomotor contributions" (f: 61).

The theme "Cognitive contributions" with the highest frequency consists of 8 (eight) sub-themes from the highest frequency to the lowest frequency as "Being acquainted with many curriculum samples" (f: 25), "Refining thinking skills" (f: 23), "Acquiring pedagogical skills" (f: 21), "Learning activity" (f: 11), "Acquiring awareness" (f: 8), "Learning not only theoretical, but also practical education" (f: 3 ), "Developing problem-solving skills" (f: 1), and "Improving imagination" (f: 1 ). As a result of the detailed analysis it was observed, meanwhile, that the sub-theme "Refining thinking skills" was divided in itself into "Multi-directional thinking" (f: 8), "Creative thinking" (f: 6), "Fast thinking" (f: 5), "Planned thinking" (f: 2), "Rational thinking" (f: 1) and "Analytical thinking" (f: 1); the sub-theme "Acquiring pedagogical skills" into "Learning to teach according to student level" (f: 11), "Learning how to transfer" (f: 7), "Learning to speak more effectively in the classroom" (f: 2 ) and "Learning what to pay attention to" (f: 1); and the sub-theme "Acquiring awareness" into "Enabling to be conscious" (f: 3), "Augmenting attention" (f: 3 ), and "Grasping the significance of extra-curricular activities" (f: 2).

The second topic with the highest frequency is the theme "Social contributions". When Figure 2 is examined, it is clear that the theme "Social contributions" is consisted of 4 (four) sub-themes from the highest frequency to the lowest frequency as "Communicating" (f: 65), "Cooperating" (f: 11), "Speaking in public" (f: 8), and "Getting to familiarize with children" (f: 6). It is observed, as a result of the comprehensive examination, that the sub-theme "Communicating" is divided in itself into "With friends" (f: 26), "With different people" (f: 18), "With teachers and principals" (f: 12), and "With students" (f: 9); and the sub-theme "Cooperating" into "Carrying out teamwork" (f: 9) and "Learning the unity and solidarity" (f: 2).

When the theme "Affectional contributions" is analyzed, it is observed that it includes, from the highest frequency to the lowest frequency, 12 (twelve) sub-themes as "Acquiring awareness" (f: 11), "Having fun" (f: 9), "Acquiring pedagogical feelings" (f: 7), "Establishing empathy" (f: 7), "Experiencing the atmosphere and emotion" (f: 6), "Being happy" (f: 5), "Becoming emotional" (f: 5), "Re-experiencing a past emotion"(f: 4), "Being eager" (f: 3), "Acquiring positive attitudes" (f: 3 ), "Strengthening the bond with student" (f: 2 ) and "Gaining self-confidence" (f: 1). It is observed, as a result of a comprehensive examination, that the sub-theme "Acquiring awareness" is divided in itself into "Being sensitive" (f: 4), "Enabling to be conscious" (f: 4), "Awareness of abilities" (f: 2 ) and "Caring about" (f: 1); and the sub-theme "Acquiring positive attitudes" into "Acquiring a favorable positive attitude for the course" (f: 2 ) and "Freeing from prejudices" (f: 1 ).

Finally, the analysis of the theme "Psychomotor contributions" revealed that the theme included, from the highest frequency to the lowest frequency, 4 (four) sub-themes as "Material preparation" (f: 26), "Development of psychomotor skills" (f: 19), "Comfortable use of body language in public" (f: 14) and "Using educational technology" (f: 2).

The sample statements which are benefited from as a source of the student opinions about the cognitive, affectional, psychomotor, and social contributions provided through the ECAE course are given below.

- $\quad$ Sample statements regarding the cognitive contributions.

S54-F "How a program is prepared; observing it both in theory and practice will enable me to cope with my teaching tasks more comfortably and more effectively."

S24-F "I do activities with a different approach because this process has enabled me to step into different ideas and thoughts for my teaching life."

S36-F "I have learned how the curriculum flow for the curriculum we present and for other curricula will be, and what the child level should be in the activities."

- Sample statements about the affectional contributions

S31-F "It has made me more sensitive for some issues we have experienced not only during our activities but also during the activities of our other friends. Such senses will do contribute me in preparing a ceremony event when I will become a teacher in the future."

S20-F "I learned what was more useful for children and I could be able to laugh childishly and had fun."

S10-F "I felt the necessity of feelings such as affection and compassion, which exists in the essence of the teaching profession."

S37-M "Some days and weeks, including the week we presented our activities, aroused in me a feeling as if I were living that moment and whatever I know about that day was being refreshed again." 
- Sample statements regarding the psychomotor contributions

S36-F "I have learned the level of a child in architecting materials, so I can design convenient materials."

S33-F "We used and developed our small muscle skills since a great majority of the activities we executed contained handicrafts."

S30-F "I became aware that it was more effective when I added my gestures and mimics while reading a text or a poem."

- $\quad$ Sample statements on the social contributions

S23-F "I believe that our communication with our classmates is increased. From time to time we helped them and sometimes they helped us. Only by making my students perform such things, I can integrate them."

S6-F "I have been in many environments and communicated with different individuals. Such a situation can also be helpful in my teaching life."

S63-F "I learned to become a unit with my team friend while performing an event. I think it will contribute to my cooperation with my colleagues in my vocational life."

\subsection{Student Opinions Regarding the Effects of ECAE Course on Communication with Stakeholders}

The question of what effects the ECAE course had on communication with stakeholders was directed to the students and the findings were given in Figure 3.

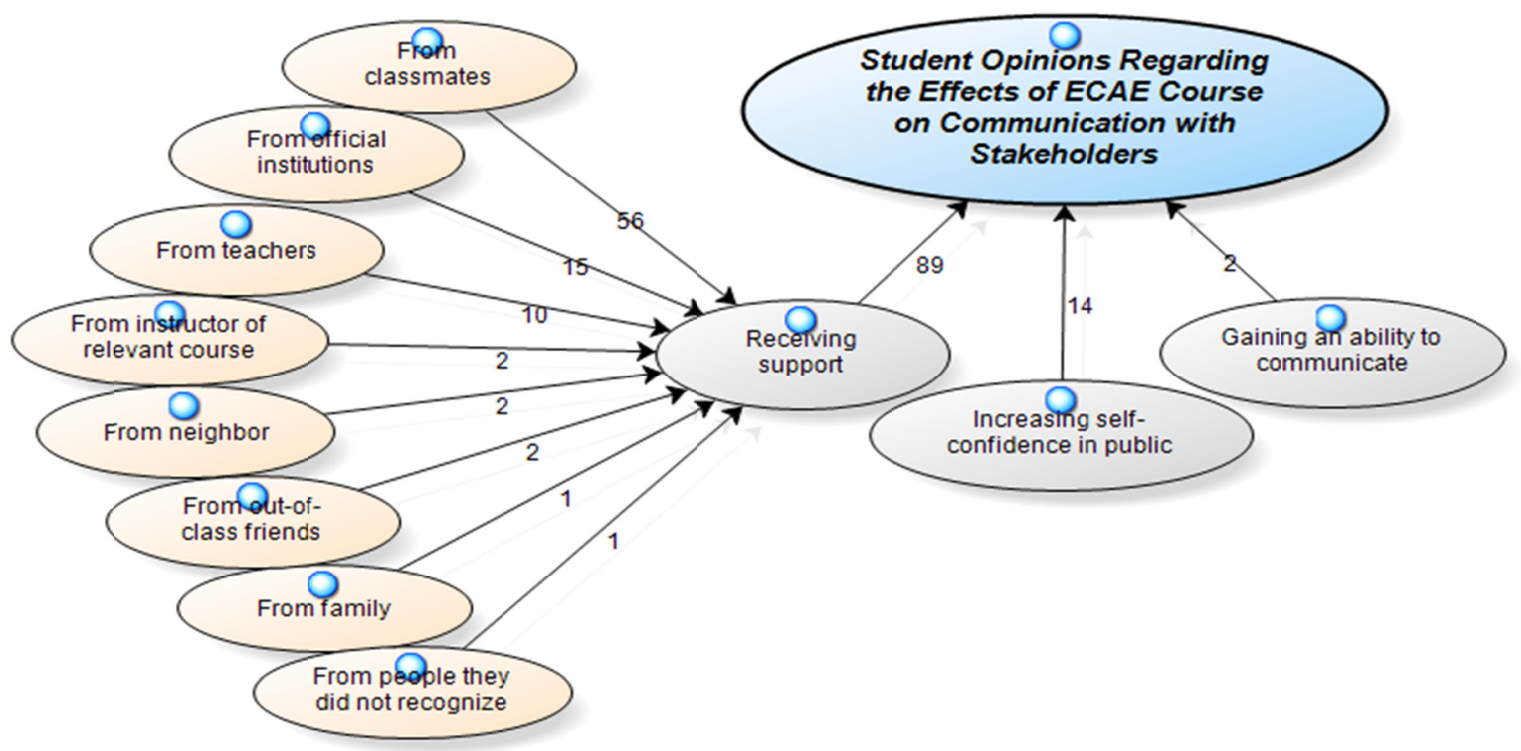

Figure 3. Student opinions regarding the effects of ECAE course on communication with stakeholders

In Figure 3, when the student opinions regarding the effects of the ECAE course on communication with stakeholders have been examined, it is observed that student opinions consist, from the highest frequency to the lowest frequency, of 3 (three) themes as "Receiving support" (f: 89), "Increasing self-confidence in public" (f: 14) and "Gaining an ability to communicate" (f: 2). As a result of an itemized survey, it was observed that the sub-theme "Receiving support" was divided in itself into "From classmates" (f: 56), "From official institutions" (f: 15), "From teachers" (f: 10), "From instructor of relevant course" (f: 2), "From neighbor" (f: 2), "From out-of-class friends" (f: 2), "From family" (f: 1) and "From people they did not recognize" (f: 1). The sample statements which are benefited from as a source for the formation of student opinions on the effect of the ECAE course on communication with stakeholders are given below.

S27-F "There has been a lot of cooperation, in line with the activities we carried out, in the classroom environment. Such cooperation has made the classroom environment even better and caused in-class communication to be increased."

S53-F "There were communication gaps in the classroom before taking this course. After taking it, however, 
when everyone helped mutually in the activities in the classroom, such gaps were eliminated, and thus I was able to communicate better."

S36-F "After we visited the Red Crescent association, it could be expressed that I became more conscious through what they had transferred to us. I learned what I considered as correct was incorrect (about first-aid). I learned better the duties of the Red Crescent. I believe, therefore, that I can instruct my surroundings through the information I have captured."

S33-F "I have got advice from the primary school teachers. They also greeted me with a smile."

S49-M "I had usually problems in such communications, and I was hesitant and bored. But I grasped that it was an unnecessary sense. So, my self-confidence was increased."

\subsection{Student Opinions on the Problems Encountered During the ECAE Course}

The question of what problems that the students encountered during the ECAE course were directed to the students and the findings were given in Figure 4.

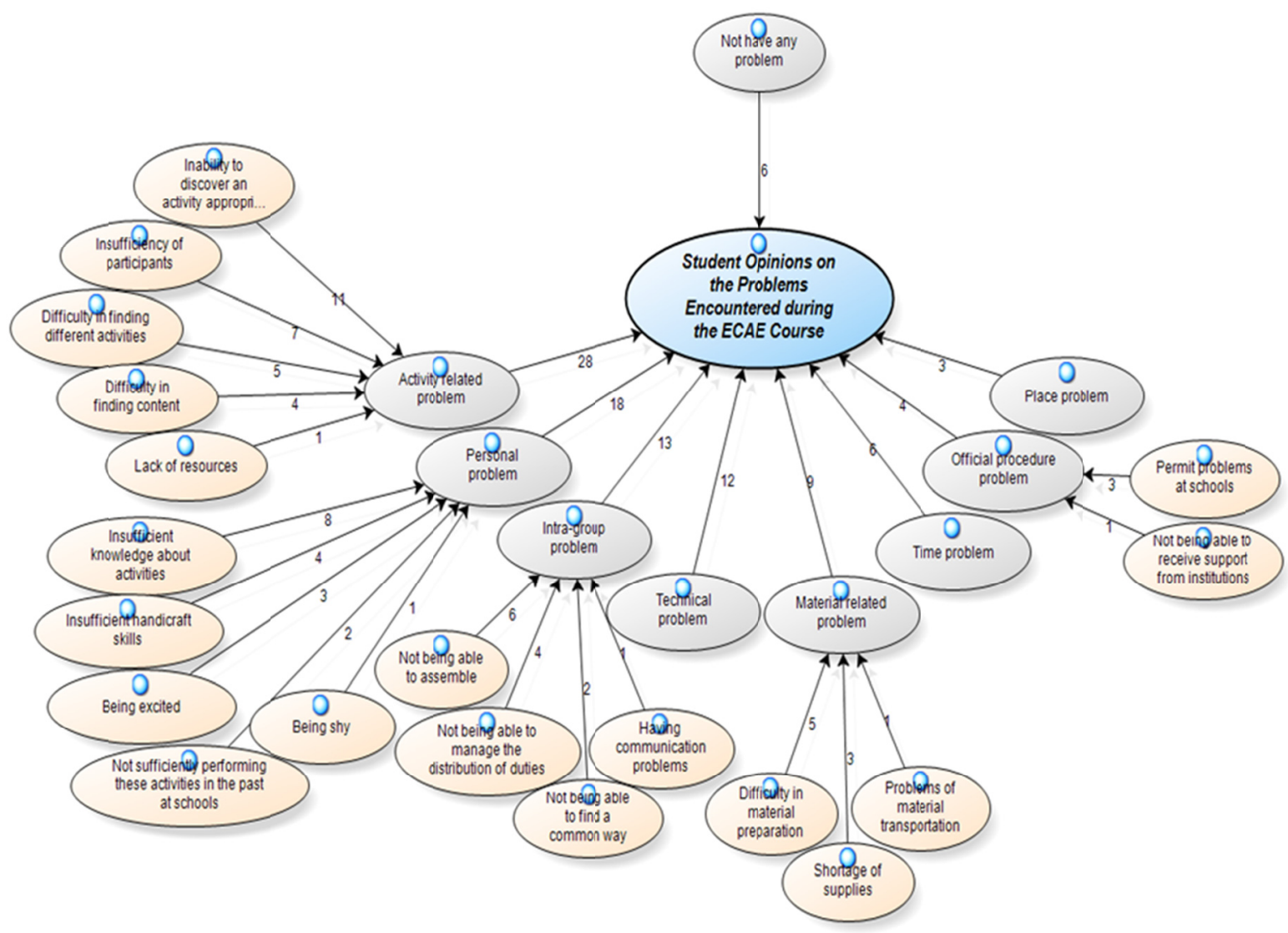

Figure 4. Student opinions on the problems encountered during the ECAE course

When the opinions of the students on the problems encountered during the ECAE course were analyzed in Figure 4 , it was observed that student opinions, from the highest frequency to the lowest frequency, were consisted of 8 (eight) themes as "Activity related problem" (f: 28), "Personal problem" (f: 18), "Intra-group problem" (f: 13), "Technical problem" (f: 12), "Material related problem" (f: 9), "Time problem" (f: 6), "Official procedure problem" (f: 4), and "Place problem" (f: 3 ) and some students expressed that they did not have any problem (f: 6). It was observed, as a result of comprehensive examination, that the theme "Activity related problem" was divided in itself into the sub-themes as "Inability to discover an activity appropriate for student level" (f: 11), "Insufficiency of participants" (f: 7), "Difficulty in finding different activities" (f: 5), "Difficulty in finding content" (f: 4) and "Lack of resources" (f: 1); the theme "Personal problem" into the sub-themes as "Insufficient knowledge about activities" (f: 8), "Insufficient handicraft skills" (f: 4), "Being excited" (f: 3), "Not sufficiently performing these 
activities in the past at schools" (f: 2 ) and "Being shy" (f: 1); the theme "Intra-group problem" into the sub-themes as "Not being able to assemble" (f: 6), "Not being able to manage the distribution of duties" (f: 4), "Not being able to find a common way" (f: 2 ), and "Having communication problems" (f: 1); the theme "Material related problem" into the sub-themes as "Difficulty in material preparation" (f: 5), "Shortage of supplies" (f: 3), and "Problems of material transportation"(f: 1); and the theme "Official procedure problem", on the other hand, into the sub-themes as "Permit problems at schools" (f: 3 ) and "Not being able to receive support from institutions" (f: 1). The example expressions that are a source for the formation of student opinions on the problems encountered in the ECAE course are given below.

S15-F "It must have been at the level of primary school, and many texts and poems were not appropriate. I had a problem with that issue."

S30-F "Our friends were not in favor of participating in and they were hesitant while preparing an event."

S35-F "Since we were the first group to submit the activities and I did not prepare such events before, I had no idea what I could do for the events. That's why I had a tough time while preparing an event."

S5-F "Since a classmate of ours was living not in a student hostel, but at home, we had difficulties in assembling and communicating with her."

\subsection{Student Opinions Regarding the Suggestions for the Problems Encountered during ECAE Course}

The question of what the students recommended to eliminate the problems encountered during the ECAE course was directed to the students and the findings were given in Figure 5.

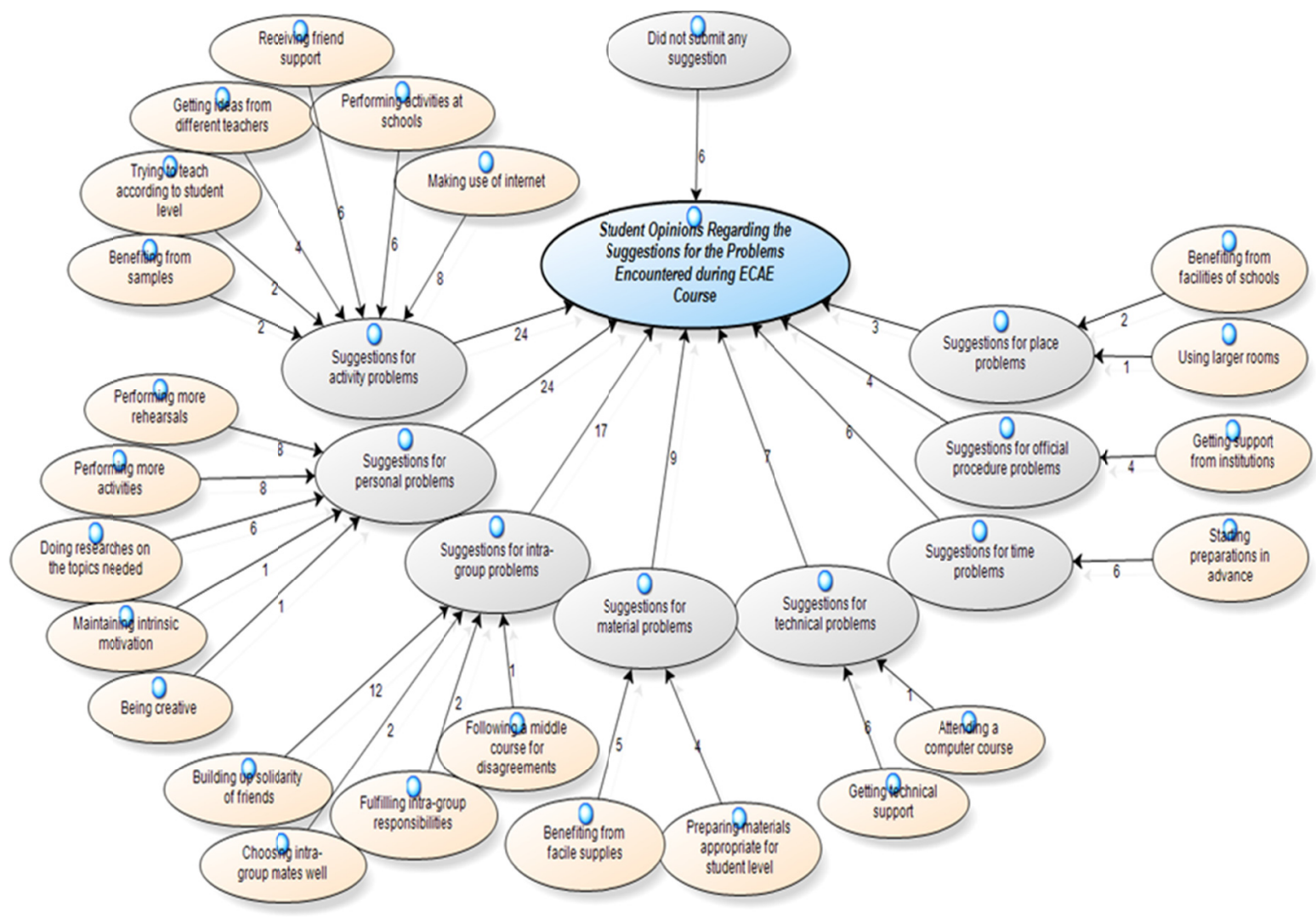

Figure 5. Student opinions regarding the suggestions for the problems encountered during ECAE course

In Figure 5, when the student opinions about the proposals for the problems encountered during the ECAE course were analyzed, it was observed that the student opinions, from the highest frequency to the lowest frequency, were consisted of 8 (eight) themes as "Suggestions for activity problems" (f: 24), "Suggestions for personal problems" (f: 24), "Suggestions for intra-group problems" (f: 17), "Suggestions for material problems" (f: 9), "Suggestions for technical problems" (f: 7), "Suggestions for time problems" (f: 6), "Suggestions for official procedure 
problems" (f: 4) and "Suggestions for place problems" (f: 3) and, meanwhile, some students did not submit any suggestion since they did not experience any problem (f: 6). It was observed, as a result of itemized survey accomplished, that the theme "Suggestions for activity problems" was divided in itself into sub-themes as "Making use of internet" (f: 8), "Performing activities at schools" (f: 6), "Receiving friend support" (f: 6), "Getting ideas from different teachers" (f: 4), "Trying to teach according to student level" (f: 2), and "Benefiting from samples" (f: 2); the theme "Suggestions for personal problems" into sub-themes as "Performing more rehearsals" (f: 8), "Performing more activities" (f: 8), "Doing researches on the topics needed" (f: 6), "Maintaining intrinsic motivation" (f: 1), and "Being creative" (f: 1); the theme "Suggestions for intra-group problems" into the sub-themes as "Building up solidarity of friends" (f: 12), "Choosing intra-group mates well" (f: 2), "Fulfilling intra-group responsibilities" (f: 2) and "Following a middle course for disagreements" (f: 1); the theme "Suggestions for material problems" into the sub-themes as "Benefiting from facile supplies" (f: 3 ) and "Preparing materials appropriate for student level" (f: 3 ); the theme "Suggestions for technical problems" into the sub-themes as "Getting technical support" (f: 6) and "Attending a computer course" (f: 1); and the theme "Suggestions for time problems" into the sub-theme "Starting preparations in advance" (f: 6). It was observed, on the other hand, that the theme "Suggestions for official procedure problems" included the sub-theme as "Getting support from institutions" (f: 4), and "Suggestions for place problems the sub-themes as "Benefiting from facilities of schools" (f: 2) and "Using larger rooms" (f: 1). Some representative statements that are a source for the formation of the student opinions on the suggestions of students to the problems encountered during the ECAE course are as follows.

S23-F "I did researches through the internet and watched representative programs."

S73-F "The students of the Faculty of Education should be able to enter primary schools only by submitting their school identity cards to perform activities."

S34-M "We can overcome our excitement only by performing more rehearsals."

S50-M "... here we are learning something altogether, and we all have to be comfortable and benevolent. The benevolence will contribute to us also when we'll become teachers in the future."

S24-F "I can perform, in advance, also the distribution of duties. I can choose my team friends better."

\subsection{Student Opinions Regarding the Effects of ECAE Course on Material Utilization Skills}

The question of what effects the ECAE course had in terms of their skills for material utilization was directed to the students and the findings were given in Figure 6.

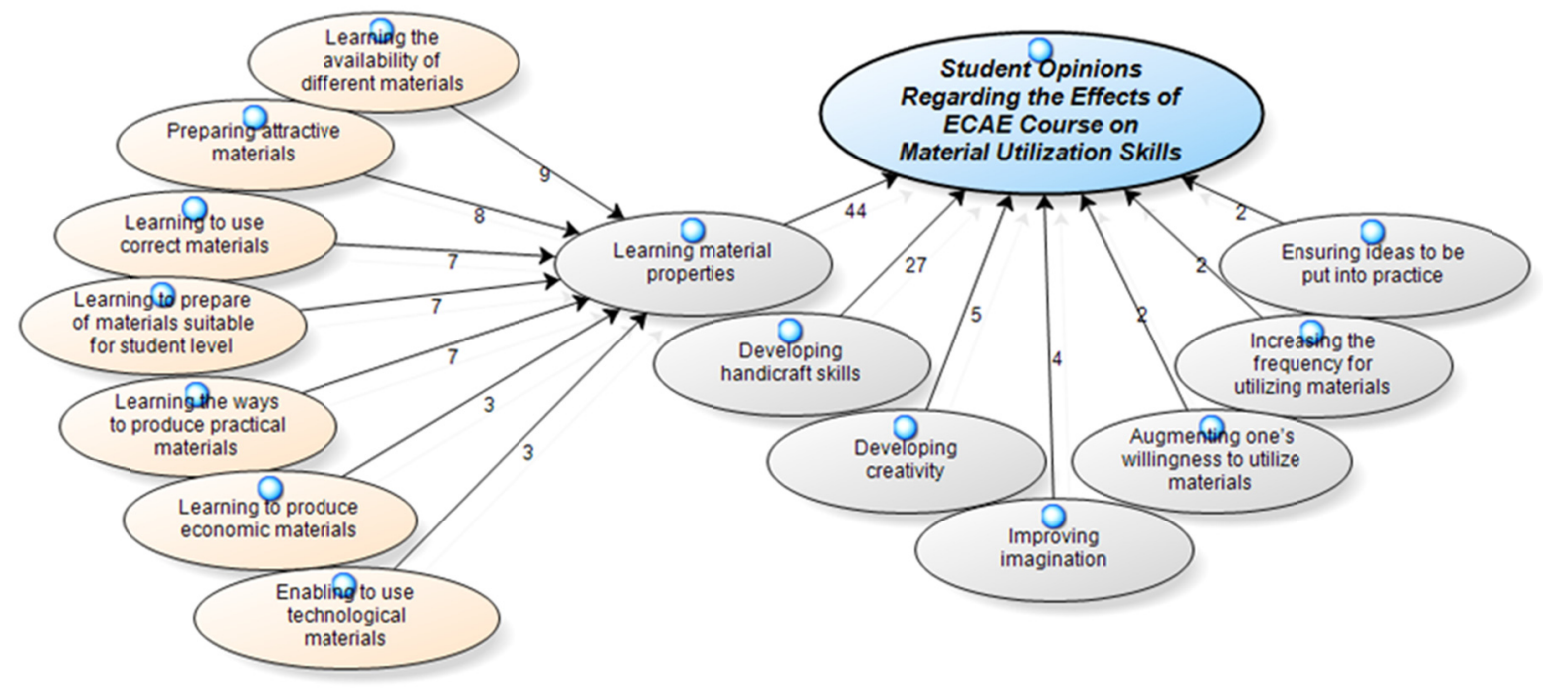

Figure 6. Student opinions regarding the effects of ECAE course on material utilization skills

In Figure 6, when the student opinions relating to skills for benefiting from materials during the ECAE course were analyzed, it was observed that student opinions, from the highest frequency to the lowest frequency, were composed of 7 (seven) themes as "Learning material properties" (f: 44), "Developing handicraft skills" (f: 27), 
"Developing creativity" (f: 5), "Improving imagination" (f: 4), "Augmenting one's willingness to utilize materials" (f: 2), "Increasing the frequency for utilizing materials" (f: 2), and "Ensuring ideas to be put into practice" (f: 2). It was observed, as a result of comprehensive analysis, that the theme "Learning material properties" was divided in itself into the sub-themes as "Learning the availability of different materials" (f: 9), "Preparing attractive materials" (f: 8), "Learning to use correct materials" (f: 7), "Learning to prepare of materials suitable for student-level" (f: 7), "Learning the ways to produce practical materials" (f: 7), "Learning to produce economic materials" (f: 3), and "Enabling to use technological materials" (f: 3). Some representative statements of students that are referred to as a source for the formation of student opinions on the effects of the ECAE course on material utilization skills are given below.

S11-F "It helped me to utilize and be acquainted with various materials."

S61-F "I became aware of different materials in different groups. It enabled me to improve myself both for ideas and handicrafts."

S29-F "The materials we utilized and prepared while organizing and implementing an activity improved my handicraft skills considerably."

S36-F "I think this course has made me skillul in fields as to how the material should be, how it attracts the attention of a child.... I've learned a lot about what to utilize while preparing materials."

S32-F "I acquired handicraft skills in the material preparation section. I made myself to be acquainted with the preparation of materials suitable for the age of a child."

\subsection{Student Opinions on the Effects of ECAE Course in Terms of Educational Technology Utilization Skills}

As a reply to the question what are the opinions of the students on the effects of the ECAE course in terms of educational technology utilization skills, the findings are given in Figure 7.

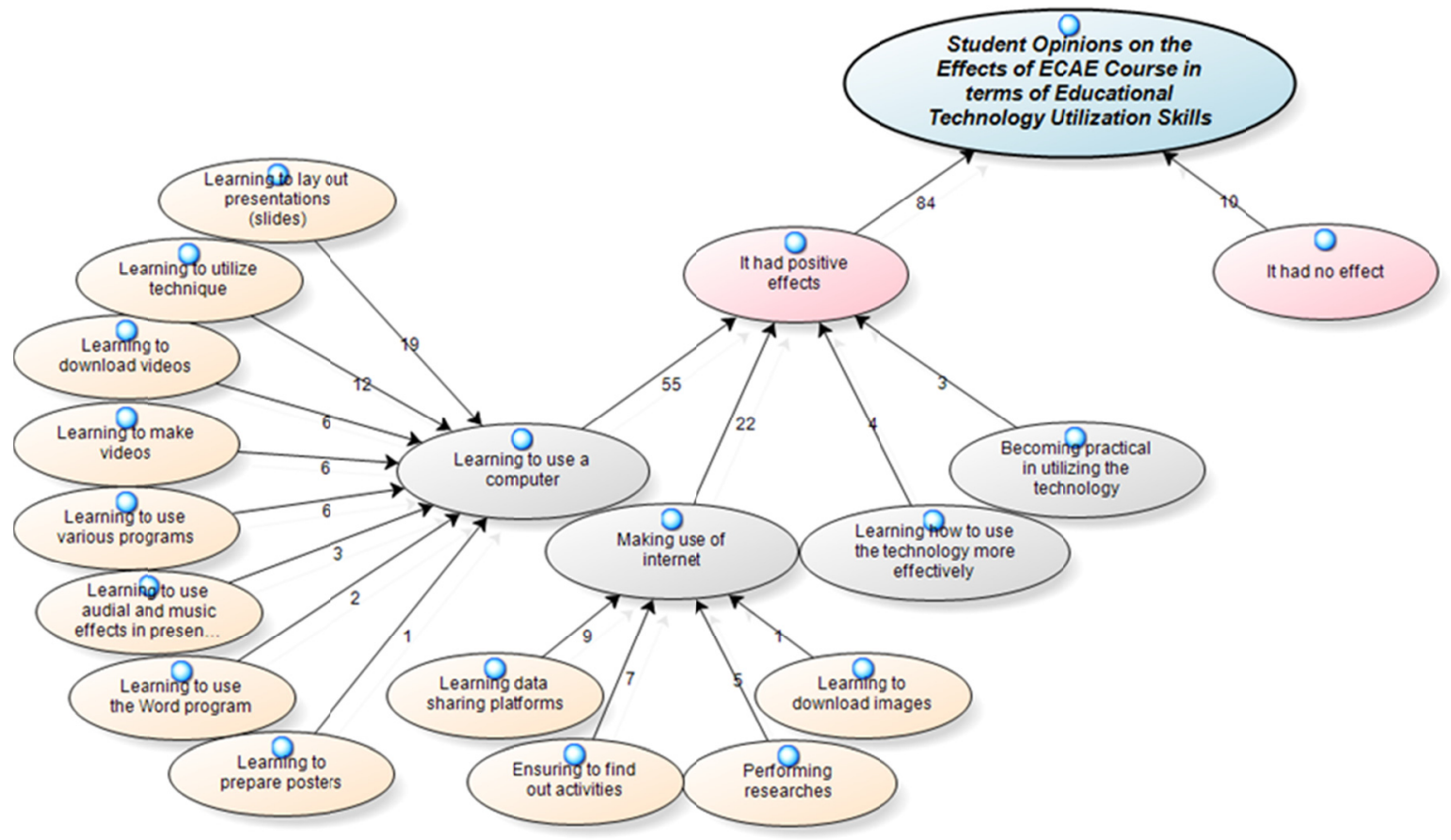

Figure 7. Student opinions on the effects of ECAE course in terms of educational technology utilization skills

In Figure 7, when the student opinions regarding the effects of ECAE course on their educational technology utilization skills were analyzed, it was observed that the great majority of students stated that the ECAE course resulted in favorable effects on the educational technology utilization skills, while some of the students declared that it did not result with any effect for them thereof. It was observed that the most favorable student opinions on the effects of ECAE course on the educational technology utilization skills were consisted, from the highest 
frequency to the lowest frequency, of 4 (four) themes as "Learning to use a computer" (f: 55), "Making use of internet" (f: 22), "Learning how to use the technology more effectively" (f: 4), and "Becoming practical in utilizing the technology" (f: 3). It was observed, as a result of comprehensive analysis, that the theme "Learning to use a computer" was divided in itself into the sub-themes as "Learning to layout presentations (slides)" (f: 19), "Learning to utilize technique" (f: 12), "Learning to download videos" (f: 6), "Learning to make videos" (f: 6), "Learning to use various programs" (f: 6), "Learning to use audial and music effects in presentations" (f: 3), "Learning to use the Word program" (f: 2) and "Learning to prepare posters" (f: 1); and the theme "Making use of internet" into the sub-themes as "Learning data sharing platforms" (f: 9), "Ensuring to find out activities" (f: 7), "Performing researches" (f: 5), and "Learning to download images" (f: 1). Some representative statements of students that are referred to as a source for the formation of opinions of them on the effects of ECAE course on the educational technology utilization skills are given below.

S29-F "I learned how to use technological instruments while laying out slides, presentations, and videos and I improved myself in this regard."

S4-M "I experienced how the educational technology should be used in a ceremony."

S36-F "... I learned to operate various programs in order to benefit from the computer more effectively."

S14-M "I became a member of data-sharing platforms. It has been helpful to me in finding out the program streams of the bodies of the Ministry of Education."

\section{Discussion}

The findings as follows were reached in consequence of the study carried out to grasp the opinions of 2nd-grade students of the Primary Teacher Education in terms of the ECAE course:

The great majority of students who participated in the research did not have any idea about this course before attending the ECAE course at the beginning of the semester. The students presumed that the ECAE course was "a course taken to perform extra-curricular activities and it was described by students in various forms such as practical, only theoretical, entertaining, useful, related to specific days and weeks, related to the values education, to be curious about, though, to be anxious about, boring, and an easy course". The aforespecified findings revealed that the students did not have accurate information about the course and they had some prejudices before taking this course. A review accomplished in the literature revealed, therefore, similar research results which proved that the university students have not got sufficient information about the extra-curricular activities (Han \& Kwon, 2018; Huang \& Chang, 2004; Kim \& Lee, 2016).

The opinions of students regarding the contributions of the ECAE course to them were collected under four themes, beginning from the highest frequency, namely as "Cognitive", "Social", "Affectional" and "Psychomotor". The student opinions regarding the cognitive contribution of the course were sorted out as "Being acquainted with many curriculum samples, refining thinking skills, acquiring pedagogical skills, learning activities, acquiring awareness, learning not only theoretical, but also practical education, developing problem solving skills, and improving imagination". The students expressed, furthermore, that they have acquired some thinking skills such as "thinking in multi-directional, creative, fast, planned, rational, and analytical" in terms of refining their thinking skills. The students stated, in terms of the sub-theme "Acquiring pedagogical skills", that they have learned some skills such as "learning to teach according to student level, how to transfer it, how to speak more effectively in classroom, and what to pay attention to". The students reported, in terms of the sub-theme "Acquiring awareness", that the ECAE course contributed them some skills such as "enabling to be conscious, augmenting attention, and grasping the significance of extra-curricular activities". That reaching some findings which improve the academic achievements and skills for problem-solving and analytical and critical images of the students in some research (Bakoban \& Aljarallah, 2015; Carbonaro \& Maloney, 2019; Eccles, Barber, Stone, \& Hunt, 2003; Wilson, 2009; Zacherman, 2010) made during extra-curricular activities at school and out of school through collaborative activities and practical experiences back up the conclusion regarding the contribution for developing thinking skills which is among the cognitive contributions of the extra-curricular activities in the current research. Avc1 and Gümüş (2019) reported in their study, backing up also the contribution as "learning not only theoretical but also practical education", which is among the student opinions on the cognitive contributions of the class in the research, that the out-of-class activities enable the students to learn by "seeing", "touching" and "doing-living" in terms of learning. The students emphasized, on the other hand, that significant (meaningful) learning was realized thanks to the activities and that they learned much better by improving their knowledge.

It was found out that the student opinions on the social contributions of the ECAE course were sorted out as "communicating, cooperating, speaking in public, and familiarizing with children". Also, the sub-theme 
"communicating" revealed some contributions of the course such as "communicating with friends, different people, teachers/principals and students"; and the sub-theme "Cooperating" resulted in some gains such as "carrying out teamwork, and learning the unity and solidarity". Additionally, teachers stated in the study conducted by Malkoç (2015) that a school environment out-of-class backed up the socialization of students. The majority of university students who participated in the study of Salmeen et al. (2019) stated, similarly, that extra-curricular activities helped them in socializing and making new friends. Daley and Leahy (2003) claimed, on the other hand, that the attitude for participation in extra-curricular activities provided students with more opportunities to interact with people outside of their current social environment and such a situation contributed to the development of their friendly relations.

When the student opinions relating to the affectional contributions, of course, were analyzed, it was observed that the course made some contributions such as "acquiring awareness, having fun, acquiring pedagogical feelings, establishing empathy, experiencing the atmosphere and emotion, being happy, becoming emotional, re-experiencing a past emotion, being eager, acquiring positive attitudes, strengthening the bond with students, and gaining self-confidence. Furthermore, the contributions provided by the ECAE course in the sub-theme "Acquiring awareness" were determined as "being sensitive, enabling to be conscious, awareness of abilities, and caring about"; and the contributions of the ECAE course in the sub-theme "Acquiring positive attitudes" were determined as "acquiring favorable positive attitude for the course and freeing from prejudices". Likewise, the students expressed in the research of Avcı and Gümüş (2019) that they learned by having fun affectively during outdoor education activities, they were excited and happy during the activities, and they generally enjoyed all of the activities. Also, some students stated that they had felt happiness and anxiety together. The study of Lewis (2004, as cited in Kuloğlu, 2019) revealed that the students gained more self-confidence when they have taken part in extra-curricular activities.

Finally, the students reported that the course provided some contributions, in terms of the theme "Psychomotor contributions", such as "material preparation, development of psychomotor skills, comfortable use of body language in public, and using educational technology." Dinçer (2009) found, of a nature supporting this finding, that the students improved their skills to express themselves in public as a result of taking part in the extra-curricular activities, and consequently, they experienced minimal effects in terms of excitement and anxiety.

When the opinions of the students regarding the effects of the ECAE course on communication with stakeholders were analyzed, it was concluded that the course resulted in gains in terms of "receiving support, increasing self-confidence in public, and gaining the ability to communicate". In addition, the students stated in the theme "Receiving support" that they got help "from classmates, from official institutions, from teachers, from the instructor of the relevant course, from the neighbor, from out-of-class friends, from family, and from people they did not recognize". Many research results back up this finding. It was concluded in research by Dinçer (2009) that the extra-curricular activities yielded some gains on student attitudes in terms of interaction and intra-group sharing. It was determined in the study of Rynes et al. (2003) that the leadership and interpersonal communication skills of the students participating in the extra-curricular activities increased accordingly. Likewise, the students who participated in the study of Rubin, Bommer and Baldwin (2002) reported that the extra-curricular activities resulted in increases in the communication skills of individuals, and participation in the extra-curricular activities was correlated to the abilities of energetic communication, taking initiative, decision-making, and teamwork. The students have become acquainted with many unfamiliar people only by participating in the extra-curricular activities and group work as claimed by Massoni (2011). The extra-curricular activities favorably improve, in general, the basic skills of individuals such as performing teamwork, self-orientation and submitting presentations that can be utilized in their future profession (Wood, Little, Goldring, \& Jenkins, 2011).

The study revealed that the problems encountered by the students during the ECAE course were related to "activity, personal, intra-group, technique, material, time, official procedure, and place". Some of the students reported that they did not have any problem. The students declared additionally under the theme "Activity related problem" that they encountered problems such as "Inability to discover an activity appropriate for a student level, insufficiency of participants, difficulty in finding different activities, difficulty in finding content, and lack of resources". The student opinions in terms of the theme "Personal problem" were consisted of "insufficient knowledge about activities, insufficient handicraft skills, being excited, not sufficiently performing these activities in the past at schools, and being shy". The students notified their opinions in terms of the theme "Intra-group problem" as "not being able to assemble, not being able to manage the distribution of duties, not being able to find a common way, and having communication problems". The students stated that they encountered problems in terms of the theme "Material related problem" such as "difficulty in material preparation, shortage of supplies, and problems of material transportation"; and in terms of the theme "Official procedure problem" such as "permit problems at 
schools" and "not being able to receive support from institutions". Similar results giving support to the existing research results have been detected in many studies accomplished. It was determined in the research conducted by Çengelci (2013) that the class hours were insufficient to do extra-curricular activities and the time problem was emphasized on thereof. It was concluded in the research conducted by Öner (2015) that the reason for not accomplishing out-of-school activities sufficiently was due to insufficient class hours and legal procedures. Malkoç (2015) claimed in his study that some factors such as course content, time, and physical structure were the basic determinants for implementing out-of-class activities, and so teachers could not perform outdoor activities at a sufficient level due to crowded classes, insufficient time, and inadequate physical structure of a school. Balcioğlu (2013) reported in his research that social activities could not be performed effectively enough due to the reasons such as lack of teachers, time, and materials when the social activities were scheduled. Gündoğdu, Karataş, and Nacar (2011) declared in their study that the principals of the school, who participated in the study, emphasized, as the most important problem, the lack of place and financial impossibilities for performing the extra-curricular events. Likewise, in the studies conducted by Ekici, Bayrakdar, and Uğur (2009) and Yaşın (2012) it was concluded that the facilities of schools were insufficient for performing the extra-curricular activities. Furthermore, Bozpolat (2016) revealed the physical place and material problems encountered during the relevant course in her study, in which she collected teacher opinions regarding the free activities course.

The analysis on the student opinions regarding the suggestions about the problems encountered during the ECAE course revealed, therefore, that the students submitted some suggestions for problems such as "activity-related, personal, intra-group, material related, technical, time, official procedure, and place" and some students did not submit any proposal since they encountered no problem. The "Suggestions for activity related problems" are composed of in itself as the proposals "making use of internet, performing activities at schools, receiving friend support, getting ideas from different teachers, trying to teach according to student level", and benefiting from samples". The suggestions such as "performing more rehearsals, performing more activities, doing researches on the topics needed, maintaining intrinsic motivation, and being creative" were submitted by the students in terms of "Suggestions for personal problems". The suggestions as "building up solidarity of friends, choosing intra-group mates well, fulfilling intra-group responsibilities, and following a middle course for disagreements" were produced regarding the "Suggestions for intra-group problems". The suggestions such as "benefiting from facile supplies and preparing materials appropriate for student level" in terms of the theme "Suggestions for material problems", and "getting technical support and attending a computer course" in terms of the theme "Suggestions for technical problems" were developed accordingly. Furthermore, the suggestions as "starting preparations in advance" for the theme "Suggestions for time problems"; as "getting support from institutions" for the theme "Suggestions for official procedure problems", and as "benefiting from facilities of schools and using larger rooms" for the theme "Suggestions for place problems" were reported. The teachers who participated in the study of Yaşin (2012) recommended, in parallel with the aforegiven results, that the place and equipment tools must be shared as required with nearby schools in order to eliminate the lack of place and equipment tools during extra-curricular activities. Furthermore, Ekici, Bayrakdar, and Uğur (2009) submitted a suggestion, taking into account the deficiencies that could not be corrected, in their study, advising an increase to be made on the school facilities in order to augment the extra-curricular activities and to carry out the activities per their real purpose, and also to benefit from schools that have facilities in terms of equipment-tools and place.

The analysis on the student opinions relating to the effects of the ECAE course on skills for material utilization revealed that the course resulted in some impacts on their skills in terms of "learning material properties, developing handicraft skills, developing creativity, improving imagination, augmenting one's willingness to utilize materials, increasing the frequency for utilizing materials, and ensuring the ideas to be put into practice". The surveys accomplished on the student opinions relating to the theme "Learning material properties" revealed, meanwhile, that the course yielded some benefits such as "learning the availability of different materials, preparing attractive materials, learning to use correct materials, learning to prepare of materials suitable for student level, learning ways to produce practical materials, learning to produce economic materials, and enabling to use technological materials. Demirel, Seferoğlu, and Yağcı (2004) argued, therefore, that an effective teacher should prepare the visual and audial tools related to his/her course in advance and make a good plan on where and how to use applicable tools. Hence, it can be claimed, taking into consideration the results collected from the present study, that the ECAE course was a functional course for the teaching profession due to its favorable contributions to the material preparation and material utilization skills of students.

Another result reached within the scope of the study is the issue regarding the effects of the ECAE course on educational technology utilization skills. In this context, while the great majority of students emphasized that the ECAE course had favorable effects on educational technology utilization skills, some students reported that it did 
not affect them thereby. The analysis on the opinions of the students who reported that the ECAE course caused positive effects on educational technology utilization skills revealed, on the other hand, that the effects, of course, were in terms of "learning to use a computer, making use of the internet, learning how to use the technology more effectively, and becoming practical in utilizing the technology. The analysis on the theme "Learning to use a computer" revealed some student opinions such as "learning to layout presentations (slides), learning to utilize the technique, learning to download videos, learning to make videos, learning to use various programs, learning to use audial and music effects in presentations, learning to use the Word program, and learning to prepare posters". The student opinions in terms of the theme "Making use of internet" revealed that the course provided some favorable effects such as "learning data sharing platforms, ensuring to find out activities, performing researches, and learning to download images". It can be claimed, in line with the results collected accordingly, that the ECAE course has improved many skills of the students concerning make use of educational technology. Katranc1 and Uygun (2013) emphasized in their study the necessity of using technology in education and also mentioned the advantages of technology such as making a course more interesting, making it easier to reach a target, providing more permanent learning, and saving time. The need for teachers to use technology effectively comes to the fore when the aforespecified advantages have been taken into consideration. Then, educational institutions need to train the students who have innate skills and self-confidence to use the technology effectively during the teaching process (Erdemir, Bakırc1, \& Eyduran, 2009).

The following suggestions have been established based upon the conclusion of the study:

- The students of the Faculty of Education should be informed, by their advisors, about the optional pedagogical classes, and the purpose and content of these classes at the beginning of the semester.

- Cooperation should be agreed upon between faculties and various institutions, and flexibility should be brought for official procedures that making the implementation stages hard for the activities to be designed by students within the scope of the ECAE course to reach their goals.

- Appropriate out-of-class places, where students can perform their activities, should be arranged.

- It should be ensured that representative extra-curricular activities are prepared at schools to be shared in digital media to increase the number and variety of resources that students can benefit from while designing the ECAE activities.

- Students should be given the chance to present, in the factual school environment, the activities they shall prepare within the scope of the ECAE course.

- Furthermore, conducting more comprehensive studies on the effectiveness of this course in different faculties, on different students, with larger subject groups, utilizing qualitative or quantitative methods will make a great contribution to the relevant field.

\section{References}

Abizada, A., Gurbanova, U., Iskandarova, A., \& Nadirzada, N. (2020). The effect of extracurricular activities on academic performance in secondary school: The case of Azerbaijan. International Review of Education, 66, 487-507. https://doi.org/10.1007/s11159-020-09833-2

Akman, Ö., Kılıç Çarşanbalı, Ç., \& Alagöz, B. (2017). Social studies teachers' views towards value education. Journal of Ahi Evran University Kırşehir Faculty of Education, 18(1), 701-720.

Akyüz, G. (2013). Evaluation of the relationship between the time spent on leisure activities of students' and their achievements in mathematics. Electronic Journal of Social Sciences, 12(46), 112-130.

Annu, S., \& Sunita, M. (2013). Impact of extracurricular activities on students in a private school of Lucknow district. International Journal of Humanities and Social Science Invention, 2(6), 92-94.

Assemi, A., \& Sheikhzade, M. (2013). Intended, implemented, and experiential null curriculum. Life Science Journal, 10(1), 82-85.

Avc1, G., \& Gümüş, N. (2019). Views of students on outdoor education. Turkish Studies Educational Sciences, 14(3), 351-377. https://doi.org/10.29228/TurkishStudies.22855

Bakoban, R., \& Aljarallah, S. (2015). Extracurricular activities and their effect on the student's grade point average: Statistical study. Educational Research and Reviews, 10(20), 2737-2744. https://doi.org/10.5897/ERR2015.2436

Balcıoğlu, İ. (2013). Social activity perceptions of teachers working in high schools (Gaziantep / Şahinbey district example) (Master's thesis). Available from National Thesis Center: Full Text (454227) 
Başkale, H. (2016). Determining validity, reliability, and sample size in qualitative research. Electronic Journal of Dokuz Eylul University Faculty of Nursing, 9(1), 23-28.

Bozpolat, E. (2016). Teachers' perceptions on free activities course in primary schools. Zeitschrift für die Welt der Türken Journal of World of Turks (ZfWT), 8(2), 217-239.

Büyükkaragöz, S. (1997). Curriculum development: Source texts. Öz Eğitim Printing Publishing.

Büyüköztürk, Ş. (2012). Data analysis handbook for social sciences (16th ed.). Pegem Akademi Publishing.

Büyüköztürk, Ş., Çakmak, E. K., Akgün, Ö. E., Karadeniz, Ş., \& Demirel, F. (2009). Scientific research methods in education (28th ed.). Pegem Akademi Publishing.

Cadwallader, T. W., Wagner, M., \& Garza, N. (2002). Participation in Extracurricular Activities. Retrieved from http://www.nlts2.org/reports/2003_04-2/nlts2_report_2003_04-2_ch4.pdf

Carbonaro, W., \& Maloney, E. (2019). Extracurricular activities and student outcomes in elementary and middle school: Causal effects or self-selection? Socius: Sociological Research for a Dynamic World, 5, 1-17. https://doi.org/10.1177/2378023119845496

Castaño, A. G., \& Kelly, T. K. (2012, 7-9 November). Sustainability in the official curriculum of the architecture programs in Latin America [Conference presentation]. PLEA2012 - 28th Conference, Opportunities, Limits \& Needs Towards an environmentally responsible architecture Lima, Perú. Retrieved from http://plea-arch.org/ARCHIVE/websites/2012/files/t09-20120124-0011.pdf

Çengelci, T. (2013). Social studies teachers' views on learning outside the classroom. Educational Sciences: Theory \& Practice, 13(3), 1823-1841.

Craft, S. W. (2012). The impact of extracurricular activities on student achievement at the high school level (Doctoral dissertation). Available from ProQuest Dissertation \& Theses: Full Text (3514737).

Daley, A. J., \& Leahy, J. (2003). Self-perceptions and participation in extra-curricular physical activities. The Physical Educator, 60(2), 13-19.

Demirel, Ö. (2014). Curriculum development in education from theory to practice. Pegem Akademi Publishing.

Demirel, Ö., Seferoğlu, S. S., \& Yağcı, E. (2004). Instructional technologies and material development. Pegem Akademi Publishing.

Demirtaş, Z. (2017). A general view to program evaluation approaches in education. Sakarya University Journal of Education, 7(4), 756-768. https://doi.org/10.19126/suje.388616

Dinçer, M. G. (2009). The effect of music lessons and extracurricular musical activities to primary school 7th-grade students on socialization (Master's thesis). Available from National Thesis Center: Full Text (235083)

Eccles, J. S., Barber, B. L., Stone, M. R., \& Hunt, J. (2003). Extracurricular activities and adolescent development. Journal of Social Issues, 59(4), 865-889. https://doi.org/10.1046/j.0022-4537.2003.00095.x

Ekici, S., Bayrakdar, A., \& Uğur, A. O. (2009). The attitudes of managers and students of secondary schools, towards interscholastic activities. International Journal of Humanities, 6(1), 430-444.

Erdemir, N., Bakırc1, H., \& Eyduran, E. (2009). Determination of pre-service teachers' self-confidence in using technology in education. Journal of Turkish Science Education, 6(3), 99-108.

Ertürk, S. (2013). Curriculum development in education (6th ed.). Edge Publishing.

Freeman, R. (2017). The relationship between extracurricular activities and academic achievement (Doctoral dissertation, National Louis University, Chicago, Illinois). Retrieved from https://digitalcommons.nl.edu/cgi/viewcontent.cgi?article=1254\&context=diss

Giroux, H. A., \& Penna, A. N. (1979). Social education in the classroom: The dynamics of the hidden curriculum. Theory ve Research in Social Education, 7(1), 21-42. https://doi.org/10.1080/00933104.1979.10506048

Goodlad. J. I. (1966). School, curriculum, and the individual. Macmillan.

Guba, E. G. (1981). Criteria for assessing the trustworthiness of naturalistic inquiries. Educational Technology Research and Development, 29(2), 75-91.

Gündoğdu, C., Karataş, Ö., \& Nacar, E .(2011). Problems of school director in terms of applying extracurricular activities. e-Journal of New World Sciences Academy, 6(1), 65-72. 
Han, A., \& Kwon, K. (2018). Students' perception of extracurricular activities: A case study. Journal of Advances in Education Research, 3(3), 131-141. https://doi.org/10.22606/jaer.2018.33002

Harrell, M. C., \& Bradley, M. A. (2009). Data collection methods, semi-structured interviews, and focus group. RAND Corporation.

Huang, Y. R., \& Chang, S. M. (2004). Academic and co-curricular involvement: Their relationship and the best combinations for student growth. Journal of College Student Development, 45(4), 391-406. https://doi.org/10.1353/csd.2004.0049

İşcan, C. D. (2019). Hidden curriculum and values education. In N. Köksal \& Z. Ayvaz Tuncel (Eds.). Extra-curricular activities in education (pp. 63-94). Pegem Akademi Publishing.

Jansen, L. (2016). The academic impact of extracurricular activities on middle school students. (Doctoral dissertation). Available from ProQuest Dissertation \& Theses: Full Text (10249513).

Katranc1, M., \& Uygun, M. (2013). Classroom teacher's perspectives about using technology in Turkish lessons. Journal of Adiyaman University Institute of Social Sciences-Special Issue of Turkish Education and Training, 6(11), 773-797. https://doi.org/10.14520/adyusbd.460

Kim, S., \& Lee, M. K. (2016). A study on students' perceptions and needs about college extracurricular programs. Journal of Learner-Centered Curriculum and Instruction, 16(9), 1-25. https://doi.org/10.22251/jlcci.2016.16.9.585

Kocayiğit, A., \& Ekinci, N. (2020). Evaluation of extra-curricular activities implemented in high schools according to teachers' opinions. OPUS International Journal of Society Researches, 16(29), 1810-1848. https://doi.org/10.26466/opus. 749109

Köse, E. (2013). A Suggestion for the Classification of Extracurricular Activities in Educational Institutions. International Journal of Turkish Literature Culture Education, 2(2), 336-353. https://doi.org/10.7884/teke.151

Krippendorff, K. (1980). Content Analysis: An introduction to its methodology. Sage.

Kuloğlu, A. (2019). Instructional technology and material design course according to teacher candidates. Turkish Journal of Educational Studies, 6(1), 33-44. https://doi.org/10.33907/turkjes.494405

Lincoln, Y. S., \& Guba, E. G. (1985). Naturalistic inquiry. Sage.

Lunenburg, F. C. (2010). Extracurricular activities. Schooling, 1(1), 1-4.

Malkoç, S. (2015). The usage of non-classroom environments in social studies education. Elementary Education Online, 14(3), 1079-1095.

Marsh, C. (1997). Understanding curriculum: Planning, management, and ideology. Falmer Press, Taylor ve Francis Inc.

Marshall, C., \& Rossman, G. B. (2014). Designing qualitative research. Sage.

Massoni, E. (2011). Positive effects of extracurricular activities on students. Essai, 9(27), 84-87.

Meadows, A. (2019). The impact of participation in extracurricular activities on elementary school students. Journal of Interdisciplinary Undergraduate Research, 11, 23-34.

Oliva, P. F., \& Gordon, W. R. (2018). The identification of the curriculum and teaching (Trans. K. Gündoğdu). In Curriculum development (pp. 1-23). Pegem Akademi Publishing.

Öner, G. (2015). Examination of the opinions of social studies teachers about outdoor history teaching. Turkish History Education Journal, 4(1), 89-121. https://doi.org/10.17497/tuhed.185618

Patton, M. Q. (2014). Qualitative research \& evaluation methods (Trans. Ed. M. Bütün \& S. B. Demir). Pegem Akademi Publishing.

Poetter, T. S., \& Badiali, B. J. (2001). Teacher leader. Eye on Education.

Posner, G. J. (2004). Analyzing the curriculum. McGraw-Hill.

Rubin, R. S., Bommer, W. H., \& Baldwin, T. T. (2002). Using extracurricular activity as an indicator of interpersonal skill: Prudent evaluation or recruiting malpractice? Human Resource Management, 41(4), 441-454. https://doi.org/10.1002/hrm.10053

Rynes, S. L., Trank, C. Q., Lawson, A. M., \& Ilies, R. (2003). Behavioral coursework in business education: 
Growing evidence of a legitimacy crisis. Academy of Management Learning \&Education, 2(3), 269-283. https://doi.org/10.5465/amle.2003.10932135

Salmeen, A., Alkhaldi, N., Alshaber; R., \& Majrashi, T. (2019). Extracurricular activities and student performance at Jubail University College. International Journal of Liberal Arts and Social Science, 7(1), $55-61$.

Taneri, P. O. (2018). School shows as extracurricular program: Teacher and student views. The Journal of Social Sciences, 5(25), 57-75. https://doi.org/10.16990/SOBIDER.4327

Tanner, J. M., \& Tanner, L. (1990). Curriculum development: Theory into practice (2nd ed.). Merrill/Prentice Hall.

Taşkın, Ç. Ş., \& Hacı̈̈meroğlu, G. (2010). Importance of pedagogy courses on preservice teachers' professional development. Journal of Pamukkale University Faculty of Education, 28(2), 165-174.

Taşoğlu, M. (2010). Activities outside school teaching geography of the student's academic effects of success (Master's thesis), Available from National Thesis Center: Full Text (264137).

Türnüklü, A. (2000). A qualitative research technique that can be used effectively in educational science research: Interview. Education Management in Theory and Practice, 6(4), 543-559.

Varış, F. (1996). Program development in education theory and techniques. Ankara University Printing.

Wilson, N. (2009). Impact of extracurricular activities on students (Master's thesis, University of WisconsinStout, Menomonie, United States). $\quad$ Retrieved from https://www2.uwstout.edu/content/lib/thesis/2009/2009wilsonn.pdf

Wood, J., Little, S., Goldring, L., \& Jenkins, L. (2011). The confidence to do things that I know nothing about skills development through extracurricular inquiry activity. Journal of Learning Development in Higher Education, 3, 2-21. https://doi.org/10.47408/jldhe.v0i3.59

Yaşın, İ. (2012). The expectations from outdoor lesson activities of teacher and students participating outdoor lesson activities in second grade primary education and secondary education (Example of the province of Yozgat) (Master's thesis). Available from National Thesis Center: Full Text (311014)

Yıldırım, A., \& Şimşek, H. (2013). Qualitative research methods in the social sciences. Seçkin Publishing.

Yildırım, Y. (2019). The effect of outdoor school activity-based values education program on students' effective citizenship values (Doctoral dissertation). Available from National Thesis Center: Full Text (609945)

YÖK (Council of Higher Education). (2007). Teacher education and faculties of education (1982-2007). Higher Education Board Publication.

YÖK (Council of Higher Education). (2018). New teacher-education undergraduate programs. Retrieved from https://www.yok.gov.tr/kurumsal/idari-birimler/egitim-ogretim-dairesi/yeni-ogretmen-yetistirme-lisans-pro gramlari

Yurdakal, İ. H. (2018). Examination of the changed program of undergraduate primary school teaching. Ulakbilge, 6(29), 1483-1499. https://doi.org/10.7816/ulakbilge-06-29-10

Zacherman, A. (2010). The relationship between involvement in extracurricular activities and academic performance (Master's thesis). Available from ProQuest Dissertation \& Theses: Full Text (1481031).

\section{Copyrights}

Copyright for this article is retained by the author, with first publication rights granted to the journal.

This is an open-access article distributed under the terms and conditions of the Creative Commons Attribution license (http://creativecommons.org/licenses/by/4.0/). 